\title{
HUBUNGAN PERILAKU DAN PENGETAHUAN KELUAGA TERHADAP KESELAMATAN PASIEN UNTUK MENCEGAH TERJADINYA BAHAYA
}

\section{Khairun nisa ginting}

\author{
Kahirunnisaginting06@gmail.com
}

\section{LATAR BELAKANG}

Peningkatan mutu dalam segala bidang khususnya dalam bidang kesehatan salah satunya melalui akreditasi Rumah Sakit menuju kualitas pelayanan Internasional. Dalam sistem akreditasi yang mengacu pada standar Joint commission International (JCI) diperoleh standar yang paling relevan terkait dengan mutu pelayanan Rumah Sakit International Patient Safety Goals (sasaran international keselamatan pasien) yang meliputi enam sasaran keselamatan pasien rumah sakit. (Kemenkes RI, 2011).

Keluarga merupakan lingkungan yang pertama dan utama bagi perkembangan individu, karena sejak kecil anak tumbuh dan berkembang dalam lingkungan keluarga. Karena itulah peranan orang tua menjadi amat sentral dan sangat besar bagi pertumbuhan dan perkembangan anak, baik itu secara langsung maupun tidak langsung (Ariani, 2009).Adapun fungsi keluarga menurut (Families, 2010). Fungsi keluarga adalah ukuran dari bagaimana sebuah keluarga beroperasi sebagai unit dan bagaimana anggota keluarga berinteraksi satu sama lain. Hal ini mencerminkan gaya pengasuhan, konflik keluarga, dan kualitas hubungan keluarga. Fungsi keluarga mempengaruhi kapasitas kesehatan dan kesejahteraan seluruh anggota keluarga Keluarga juga merupakan lingkungan pertama dalam proses tumbuh kembang individu.

keluarga yang harmonios akan memberikan dampak positif terhadap optimalnya perkembangan individu namun tentu saja tidak ada keluarga tanpa konflik,tanpa dinamika,atau tanpa masalah.Dalam olson \& Defrain (2010) dikemukakan bahwa keluarga akan saling memberikan dukungan fisik,moral,dan ekonomi. Keluarga merupakan bagian dari tim 
pengobatan dan perawatan. Apalagi di Indonesia dengan kultur sosialnya tinggi ditambah keterbatasan jumlah perawat di rumah sakit sehingga tugas merawat orang sakit yang dirawat di rumah sakit umumnya dilakukan oleh keluarga yang menjaga. Para anggota keluarga menunggui secara bergantian, bahkan sering menjaga bersama-sama.

Sementara perawat di rumah sakit yang memeliki bebarapa tugas yang harus merawat pasien lain di bangsal perawatan. Maka, peran keluarga penting untuk memantau kebutuhan pasien dari laporan perawat atau jika perlu malakukan komunikasi langsung.komite Keselamatan Pasien Rumah Sakit/KKPRS(2008)mendefinisikan bahwa keselamatan,(safety) adalah bebas dari harm/cedera yang tidak seharusnya terjadi atau bebas dari harm yang potensial akan terjadi

Keselamatan Pasien (Patient Safety) merupakan sesuatu yang jauh lebih penting dari pada sekedar efisiensi pelayanan. Perilaku perawat dengan kemampuan perawat sangat berperan penting dalam pelaksanaan keselamatan pasien. Perilaku yang tidak aman, lupa, kurangnya perhatian/motivasi, kecerobohan, tidak teliti dan kemampuan yang tidak memperdulikan dan menjaga keselamatan pasien berisiko untuk terjadinya kesalahan dan akan mengakibatkan cedera pada pasien, berupa Near Miss (Kejadian Nyaris Cedera/KNC) atau Adverse Event (Kejadian Tidak Diharapkan/KTD) selanjutnya pengurangan kesalahan dapat dicapai dengan memodifikasi perilaku. Perawat harus melibatkan kognitif, afektif dan tindakan yang mengutamakan keselamatan pasien. World Health Organization (WHO).

\section{METODE}

Penelitian ini menggunakan metode penelitian kualitatif fenomenologi dengan pengumpulan data melalui wawancara dan double check. serta Literature review dengan cara menganalisis, kajian dan eksplorasi jurnal, text book, maupun e-book yang relevan dan membahas evaluasi asuhan keperawatan pada pasien baru. Adapun jurnal yang digunakan pada literature review ini adalah jurnal yang diterbitkan dari kurun waktu 10 tahun terakhir didapatkan dengan menggunakan 2 database Portal Garuda dan Google Scholar.

\section{HASIL}

Dari jurnal yang telah dipilih yaitu e-journal Keperawatan (e-Kp) Volume 4 Nomor 2, Juli 2016. kemampuan melaksanakan patient safety dalam mengidentifikasi pasien, pengurangan 
resiko infeksi dan pengurangan resiko infeksi, keseluruhannya semua baik; terdapat hubungan antara perilaku dengan kemampuan perawat dan keluarga dalam melaksanakan keselamatan pasien (patient safety) tentang mengidentifikasi pasien di Ruang Akut IGD RSUP Prof Dr. R. D. Kandou Manado

Dari jurnal J. Kesehat. Masy. Indones. 12(2): 2017 Ada hubungan antara tingkat pendidikan, tingkat pengetahuan, dukungan keluarga dan peran petugas kesehatan dengan tingkat kepatuhan menjalani pengobatan hipertensi. Rendahnya tingkat pendidikan, tingkat pengetahuan, dukungan keluarga dan peran petugas. Diharapkan penderita agar teratur melakukan sesuai dengan anjuran dokter dan menjalankan pola hidup sehat sehingga dapat meminimalisir kemungkinan komplikasi yang dapat terjadi. Agar keluarga penderita dapat berperan aktif untuk selalu memberikan motivasi dan dukungan kepada anggota keluarga yang menderita hipertensi agar selalu rutin minum obat dan senantiasa patuh dalam melakukan mengobatan ke tempattempat pelayanan kesehatan. Petugas kesehatan diharapkan Memberikan pendidikan kesehatan kepada penderita rawat jalan di Puskesmas Gunungpati dan pendidikan kesehatan tersebut sebaiknya tidak hanya diberikan kepada penderita saja, namun juga kepada keluarga dan orang terdekat penderita dapat ikut serta mengingatkan dan memberikan motivasi pada penderita.

Dari jurnal JKEP.Vol.5 No. 1 Mei hlm 84 - 100 Edukasi Kesehatan meningkatkan pengetahuan dan keterampilan keluarga dalam pencegahan risiko jatuh pada Lansia. Penelitian ini bertujuan untuk mengetahui pengaruh edukasi pada keluarga dalam pencegahan risiko jatuh pada lansia sebelum dan sesudah diberikan intervensi berupa penyuluhan kesehatan.

\section{PEMBAHASAN}

Pengetahuan dapat diartikan sebagai kumpulan informasi yang dipahami, diperoleh dari proses belajar selama hidup dan dapat dipergunakan sewaktu-waktu sebagai alat penyesuaian diri, baik terhadap diri sendiri maupun lingkungan. Dapat disimpulkan bahwa pengetahuan penderita dapat menjadi guru yang baik bagi dirinya, dengan pengetahuan yang dimiliki akan mempengaruhi kepatuhan penderita tersebut dalam menjalani pengobatan. Penderita yang mempunyai pengetahuan tinggi cenderung lebih patuh berobat daripada penderita yang berpengetahuan rendah. 
Hasil penelitian menunjukkan bahwa anggota keluarga yang memberikan dukungan secara baik serta menunjukkan sikap caring kepada anggota keluarga yang menderita memiliki peran penting dalam kepatuhan berobat. Perhatian anggota keluarga mulai dari mengantarkan ke pelayanan kesehatan, membantu pembiayaan berobat, mengingatkan minum obat, terbukti lebih patuh menjalani pengobatan dibandingkan dengan penderita yang kurang mendapatkan perhatian dari anggota keluarganya. Dukungan keluarga sangat diperlukan oleh seorang penderita, karena seseorang yang sedang sakit tentunya membutuhkan perhatian dari keluarga. Keluarga dapat berperan sebagai motivator terhadap anggota keluarganya yang sakit (penderita). sehingga mendorong penderita untuk terus berpikir positif terhadap sakitnya dan patuh terhadap pengobatan yang dianjurkan oleh tenaga kesehatan.

Dengan pengetahuan yang diperoleh maka pasien akan mengetahui manfaat dari saran atau nasihat petugas kesehatan sehingga akan termotivasi untuk lebih patuh menjalani pengobatan yang dianjurkan oleh petugas kesehatan. Tidak adanya hubungan antara status pekerjaan dengan tingkat kepatuhan dalam menjalani pengobatan sejalan dengan penelitian yang menunjukan bahwa tidak ada hubungan antara pekerjaan dengan kepatuhan pengobatan.

Notoatmodjo 2007 mngemukakan bahwa pengetahuan merupakan hasil dari penginderaan terhadap suatu obyek tertentu, pengetahuan atau kognitif merupakan domain yang sangat tinggi untuk terbentuknya tindakan seseorang (over behavior).

Perawat dalam memberikan asuhan keperawatan kepada pasien harus menerapkan keselamatan pasien. Perawat harus melibatkan kognitif, afektif, dan tindakan yang mengutamakan keselamatan pasien. Perawat dalam memberikan asuhan keperawatan harus penuh dengan kepedulian. Persepsi perawat untuk menjaga keselamatan pasien sangat berperan penting dalam pencegahan, pengendalian, dan peningkatan keselamatan pasien. (Choo dkk, 2011). Dalam pelaksanaan program patient safety di rumah sakit berkareditasi, kejadian pasien jatuh merupakan salah satu indikator berjalan tidaknya program ini.

Teori Bloom 1908 dalam buku Notoatmodjo, 2003 menyatakan bahwa perilaku dapat diukur dalam 3 domain yaitu pengetahuan (knowledge) yang artinya kognitif, sikap (attitude) yang artinya afektif dan tindakan (practice) yang artinya psikomotor. Teori ini dimodikasikan untuk pengukuran hasil pendidikan kesehatan. Jika memiliki perilaku atau bawaan baik maka 
akan berdampak baik juga bagi lingkungannya. Dalam penelitian Lusia 2014, menunjukkan sebagian besar perawat berperilaku baik dalam melaksanakan keselamatan pasien di Ruang Rawat Inap Rumah Sakit. Mengidentifikasi pasien dilakukan sejak awal masuk Rumah Sakit dengan dua identitas, nama dan nomor rekam medis yang telah tertera di gelang pasien dan pada saat pemasangan gelang pasien akan di jelaskan oleh perawat manfaat gelang dan resiko yang akan timbul jika tidak pasang gelang identitas (JCI, 2011).

Perilaku perawat dalam melaksanakan keselamatan pasien mengacu pada standar keselamatan pasien Joint Commission International (JCI) dan berdasarkan permenkes no 1691/menkes/per/VII/2011 yang paling relevan terkait dengan mutu pelayanan rumah sakit yakni International Patient Safety Goals yang meliputi 6 sasaran, salah satunya identify patient correctly (Kemenkes, 2011). Hasil penelitian Anggriani, 2014 dengan judul; "Hubungan Penegetahuan Perawat dengan Penerapan Identify Patient Correcly di RSUP Ratatotok Buyat Kabupaten Minahasa Tenggara". Penelitian ini menyimpulkan sebagian besar memiliki pengetahuan baik mengenai identify patient correctly.

Patient Safety (keselamatan pasien) adalah suatu prosedur atau proses dalam suatu rumah sakit yang memberikan pelayanan pasien yang lebih aman (JCI, 2011). Dimana dipengaruhi oleh perilaku dan penerapan dari perawat pelaksanaan yang mengutamakan kepentingan keselamatan pasien

> Standar Keselamatan Pasien sebagaimana dimaksud pada ayat (2) huruf a meliputin standar:

a. hak pasien;

b. pendidikan bagi pasien dan keluarga;

c. Keselamatan Pasien dalam kesinambungan pelayanan;

d. penggunaan metode peningkatan kinerja untuk melakukan evaluasi dan peningkatan Keselamatan Pasien;

e. peran kepemimpinan dalam meningkatkan Keselamatan Pasien;

f. pendidikan bagi staf tentang Keselamatan Pasien; dan

g. komunikasi merupakan kunci bagi prtugas kesehatan untuk mencapai Keselamatan Pasien. 
Salah satu sasaran keselamatan pasien adalah tercapainya pengurangan resiko infeksi terkait pelayanan kesehatan. Infeksi adalah inivsai tubuh oleh pathogen atau mikroorganisme yang mampu menyebabkan sakit. Rumah sakit merupakan salah satu tempat yang paling mungkin rentan mendapat infeksi karena mengandung populasi mikroorganisme yang sangat tinggi dengan jenis virus yang mungkin resisten terhadap antibiotik (Potter \& Perry, 2005) Infeksi umumnya dijumpai dalam semua bentuk pelayanan kesehatan termasuk infeksi saluran kemih terkait kateter, infeksi aliran darah (blood stream infections) dan pneumonia (sering kali dihubungkan dengan ventilasi mekanis).

Menurut peneliti, resiko terinfeksi terjadi karena petugas kesehatan yang tidak mempunyai kesadaran dan tanggung jawab. Jika petugas kesehatan melakukan tugas mereka dengan baik dengan mencuci tangan sebelum dan sesudah kontak dengan pasien ataupun bersentuhan dengan benda ataupun lingkungan dengan pasien. Dan menjelaskan kepada pihak keluarga juga ikut mencuci tangan sesuai dengan pedoman 5 momen yang sudah diterapkan di rumah sakit.

(Lestari, 2012). Salah satu peningkatan mutu pelayanan keselamatan pasien yaitu pencegahan dan pengurangan resiko infeksi dengan program yang diterapkan yaitu hand hygiene yang efektif terutama 5 momen (WHO, 2009) Penelitian Fradana, 2015 dengan judul: "Improved Health To Achieve Zero Accident Throught a Patient Safety Committe" menyimpulkan bahwa pengurangan resiko infeksi terkait pelayanan kesehatan yang paling gampang adalah dengan cara mencuci tangan, karena mencuci tangan adalah salah satu langkah yang paling penting. Hal ini sesuai dengan toeri Vine (2000) mencuci tangan adalah kegiatan membersihkan tangan dari kotoran dengan air dan sabun.

Dalam hal ini dilingkungan rumah sakit sangat digalakkan hand hygiene yang efektif ini dalam rangka untuk mencegah infeksi nasokomial. Menurut peneliti, rumah sakit merupakan tempat yang rentan terjadi infeksi nosokomial atau infeksi baru selama perawatan, dan peran perawat dalam upaya pengurangan resiko infeksi akan selalu dijelaskan kepada pasien ataupun pihak keluarga untuk melakukan program mencuci tangan sebelum dan sesudah. Didepan tiap ruangan-ruangan di Ruang Akut juga sudah terdapat disinfektan.

Hal ini menunjukkan bahwa kepedulian yang tinggi untuk mencegah infeksi yang ada di rumah sakit. Dan hasil observasi dari peneliti menunjukkan sebagian besar perawat telah 
menerapkan tindakan untuk mengurangi infeksi dengan mencuci tangan sebelum dan sesudah melakukan tindakan Namun masih beberapa perawat yang belum memprioritaskan cuci tangan adalah salah satu hal yang sangat penting, sehingga belum mencapai $100 \%$.

\section{PENUTUP}

Keluarga merupakan bagian dari tim pengobatan dan perawatan. Apalagi di Indonesia dengan kultur sosialnya tinggi ditambah keterbatasan jumlah perawat di rumah sakit sehingga tugas merawat orang sakit yang dirawat di rumah sakit umumnya dilakukan oleh keluarga yang menjaga pasien,maka dari itu perlu di berikan penkes (Pendidikan kesehatan) pada keluarga mengenai langkah langkah tentang keselamatan pada pasien sehingga pada saat dirumah sakit maupun di rumah pasien dapat terhindar akan bahaya ketika petugas kesehatan tidak melakukan tindakan sesuai dengan kebutuhan pasien 


\section{DAFTAR PUSTAKA}

Bernadeta dan Ani. 2015. Pengetahuan Perawat tentang Keselamatan Pasien dengan Pelaksanaan Prosedur Keselamatan Pasien Rumah Sakit (KPRS) di Rumah Sakit Panti Waluyo Sawahan Malang. Jurnal CARE, Vol 3, No 1

Cahyono, JB. 2008. Membangun Budaya Keselmatan Pasien dalam Praktik Kedokteran. Yogyakarta: Penerbit Kanisius

Choo, dkk. (2010). Nurse's role in medication safety. Journal of Nursing Management, 18 (5).

Dewi, M. 2012. Pengaruh pelatihan timbang terima pasien terhadap penerapan keselamatan pasien oleh perawat pelaksana di RSUD Raden Mattaher Jambi. Jurnal Health \& Sport, Vol. 5, No. 3.

Elrifda, Solha. 2011. Budaya Patient Safety dan Karakteristik Kesalahan Pelayanan: Implikasi Kebijakan di Salah Satu Rumah Sakit di Kota Jambi. Jurnal Kesehatan Masyarakat Nasional Vol. 6, No. 2

Lombogia, angelita, dkk. (2016). Hubunga perilaku dengan kemampuan perawat dalam melaksanakan keselamatan pasien (patient safety) di ruang akut instalasi gawat darurat RSUP PROF. DR. R. D. KANDOU MANADO. e-journal Keperawatan (e-Kp) ( 4) . 2

Nurhasanah,aan, dkk. (2020). Edukasi kesehatan meningkatkan pengetahuan dan keterampilan keluarga dalam pencegahan jatuh pada lansia. JKEP.(5). 1

Puspita, exa , dkk. (2017). Peran keluarga dan petugas kesehatan dalam kepatuhan pengobatan penderita hipertensi di puskesmas gunung pati kota semarang . J. Kesehat. Masy. Indones. 12(2)

Simamora, R. H. (2019). Buku ajar pelaksanaan identifikasi pasien. Uwais Inspirasi Indonesia.

Soeroso. S., 2003. Manajemen Sumber Daya Manusia Di Rumah Sakit Suatu Pendekatan Sistem. EGC, Jakarta.

Sunaryo, 2004. Psikologi Untuk Keperawatan. Penerbit Buku Kedokteran EGC, Jakarta. 